\title{
EFFECT OF ANTHROPOGENIC POLLUTANTS ON THE QUALITY OF SURFACE WATERS AND GROUNDWATERS IN THE CATCHMENT BASIN OF LAKE BIALSKIE
}

\author{
Krzysztof Jóźwiakowski', Agnieszka Listosz', Magdalena Gizińska-Górna', \\ Aneta Pytka', Michał Marzec', Bożena Sosnowska ${ }^{2}$, Alina Kowalczyk-Juśko', \\ Antoni Grzywna' ${ }^{1}$, Andrzej Mazur' ${ }^{1}$, Radomir Obroślak' ${ }^{1}$
}

1 Department of Environmental Engineering and Geodesy, University of Life Sciences in Lublin, Leszczyńskiego 7 Str., 20-069 Lublin, Poland, e-mail: krzysztof.jozwiakowski@up.lublin.pl, agnieszka.listosz@up.lublin.pl, madziagizinska@tlen.pl, anetapytka@poczta.fm, michal.marzec@up.lublin.pl, alina.jusko@up.lublin.pl, antoni.grzywna@up.lublin.pl, amazur70@op.pl, radomir.obroslak@up.lublin.pl

2 Department of Biotechnology, Human Nutrition and Food Commodities, University of Life Sciences in Lublin, ul. Skromna 8, 20-704 Lublin, Poland, e-mail: bozena.sosnowska@up.lublin.pl

Received: 2016.06.30

Accepted: 2016.08.16

Published: 2016.09.30

\begin{abstract}
The work evaluates the effect of anthropogenic pollutants on the quality of water in

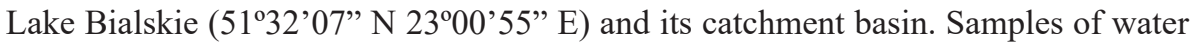
were taken from the lake (4 sampling points) and from wells dug within the catchment basin. The quality of water was analysed in May, June, August and November 2015. In the wells only in single cases was the level of chemical pollution found to exceed drinking water standards. However, in all samples the standard content of manganese was exceeded. In waters from the lake the concentrations of total phosphorus, which can contribute to eutrophication were recorded above the standard level. Both in waters from the lake and from the well a large count of meso- and psychrophiles and Coli and faecal coliforms as well as faecal Enterococci was found, which points to a high degree of contamination of the analysed waters with anthropogenic faeces. The phenomenon was observed to intensify in summer months, which can be associated with increased tourist traffic around the lake in this period.
\end{abstract}

Keywords: quality of waters, surface waters, groundwaters, lake catchment basin, anthropogenic pollutants

\section{INTRODUCTION}

The purity of water in a water reservoir depends on many factors. However, the amount of pollutants is associated with the type of catchment basin adjacent to the specific lake [KuczynskaKippen et al. 2004]. Urbanisation, intensive agricultural production and industrial activity within the area of catchment basins or watercourses have a significant impact on the quality of waters [Bedla and Król 2014]. Pressure caused by human activity (anthropopressure) is the biggest hazard to the quality of surface waters. Agricultural catchments and rural areas are believed to be among the main sources of pollution and eutrophication of surface waters [Durkowski and Woroniecki 2001]. The largest share in deteriorating the quality of water in rural areas is that of substances penetrating from the surface of the ground, so-called diffuse pollutants and household and farm sewage. Penetrating into surface waters they cause adverse changes leading to a decrease in natural values, and sometimes even to the destruction of water ecosystems (eutrophication, decay of organisms in connection with the use of pesticides) [Grzywna 2014; Niemirycze et al. 1993]. The most significant environmental pressures include: significant intake of water for household purposes, dis- 
posal of insufficiently treated sewage into surface waters or soil, agricultural runoffs charged with biogenic compounds and improper performance of agrotechnical operations, lack of infrastructure for disposal of precipitation and meltwater, in particular from cities, intensive utilisation of leisure functions and excessive tourist traffic [WIOŚ 2014; Romańczuk et al. 2013].

The purpose of the work was to evaluate the effect of anthropogenic pollutants on the quality of water in Lake Bialskie and its catchment basin. The physico-chemical and sanitary composition of water from the lakes and groundwaters directly in its neighbourhood was analysed in the light of regulatory requirements and in connection with the impact of potential sources of pollution within the catchment basin.

\section{DESCRIPTION OF THE OBJECT OF STUDY}

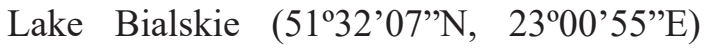
forms a part of the group of lakes called Pojezierze Łęczyńsko-Włodawskie. It is situated near Parczew, in the village Białka, gmina (administrative district) Dębowa Kłoda. Its surface is $31.7 \mathrm{ha}$, and the volume 2158 thousand $\mathrm{m}^{3}$. The lake is oval-shaped. It is $728 \mathrm{~m}$ long, $526 \mathrm{~m}$ wide, while its shoreline is $2038 \mathrm{~m}$ long. The mean depth of the lake is $6.8 \mathrm{~m}$, and the maximum is $18.2 \mathrm{~m}$. According to the survey by the Regional Inspectorate for Environmental Protection in 2005 the lake was assigned purity class II (good) [WIOŚ 2006b].

The catchment basin of Bialskie Lake covers an area of $1.3 \mathrm{~km}^{2}$ [WIOŚ 2006a], and the village Białka is situated within its territory. In summer the lake is intensively used for leisure purposes. With regard to the recreational use of the lake, the

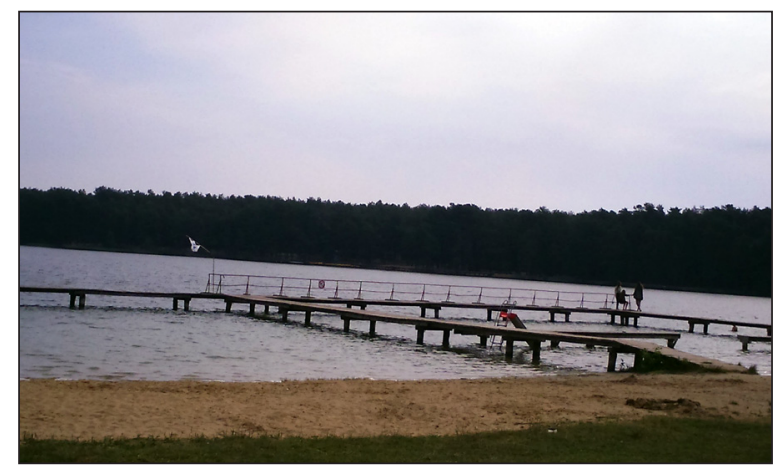

Photo 1. Sampling point no. 5 (photo: M. Gizińska-Górna) village offers many holiday resort, lodges, campsites and tent sites. Data provided by the Gmina Office in Dębowa Kłoda suggests that Białka has 250 permanent residents, while in summer the number of tourists visiting the lake increases up to 3000 . Such a large number of tourists can have a negative impact on the purity of waters in Lake Bialskie.

\section{MATERIALS AND METHODS}

In order to accomplish the study objective the quality of surface waters in Lake Bialskie and groundwaters in its catchment area was analysed. Eight water sampling points were selected for analyses. Four of them (no. 1-4) were dug wells, and the remaining four points were located within the limits of the lake near potential sources of anthropogenic pollutants. Points no. 5, 7, 8 were situated near holiday resorts, and point no. 6 - in bulrush (Fig. 1; Phot. 1-4).

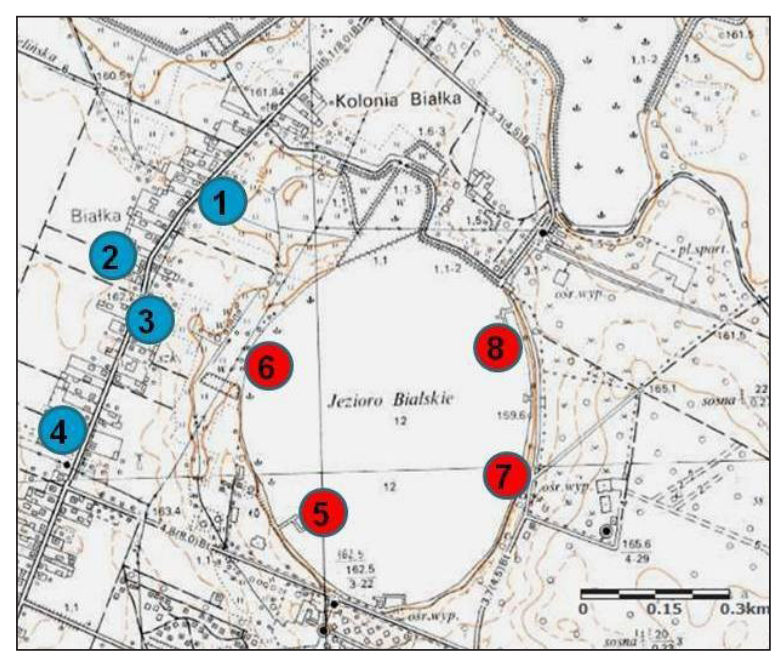

Figure 1. Location of water sampling points within the catchment area of Lake Bialskie

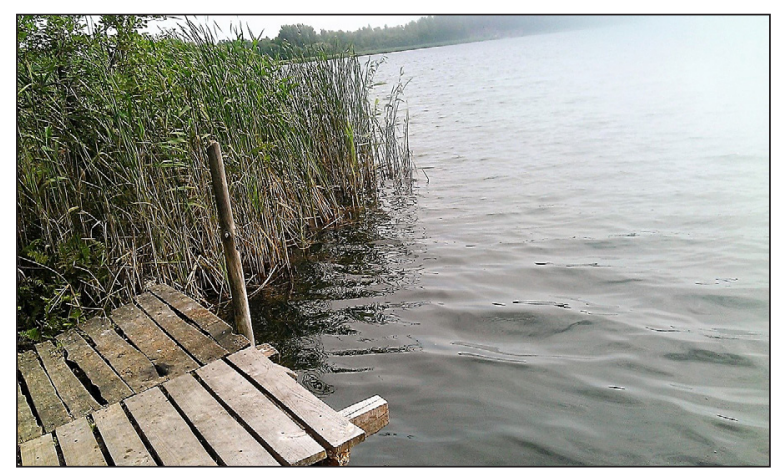

Photo 2. Sampling point no. 6 (photo: M. Gizińska-Górna) 


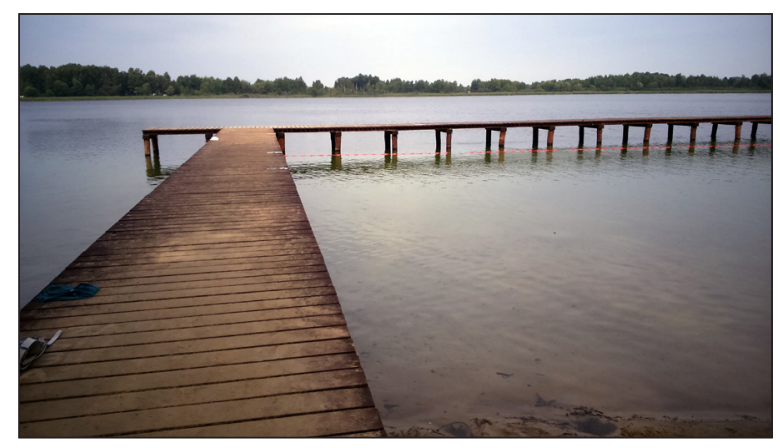

Photo 3. Sampling point no. 7

(photo: M. Gizińska-Górna)

The quality of water was analysed in May, June, August and November 2015. The following indicators were determined in lake water samples: temperature, $\mathrm{pH}$, concentration of dissolved oxygen, electrolytic conductivity, total suspended solids, $\mathrm{BOD}_{5}, \mathrm{COD}_{\mathrm{Cr}}$, total nitrogen, ammonia, nitrates, nitrites, as well as total phosphorus and phosphates.

In water from the wells $\mathrm{pH}$ and electrolytic conductivity were measured, and the concentrations of ammonia, nitrates, nitrites, chlorides, sulphates, iron and manganese were determined. Physico-chemical analyses were carried out according to commonly used methods [Hermanowicz et al. 1999]. In addition, the count of Coli, faecal coliforms, Enterococci and count of mesophiles and psychrophiles were determined in water samples according to methods described in Polish Standards [PN-C-04615-05:1975P; PN-C-04615-07:1977P; PN-ISO 6222:1999; PN-C-04615-25:2008P].

Physico-chemical analyses were performed in the Laboratory of Water and Sewage Analyses of the Department of Environmental Engineering and Geodesy of the University of Life Sciences in Lublin. Microbiological parameters were determined in the Laboratory of Plant Origin Organic Food at the Department of Biotechnology, Human Nutrition and Food Commodities of the University of Life Sciences in Lublin.

The results of physico-chemical testing of water from the lake were compared with the limit values of quality indicators determined in the Regulation of the Minister of Environment of 11 February 2004 and of 22 October 2014 on the method of classification of uniform parts of surface waters and environmental quality standards for priority substances [Regulation of the Minister of Environment 2004, 2014]. Whereas, the results of microbiological analyses were compared

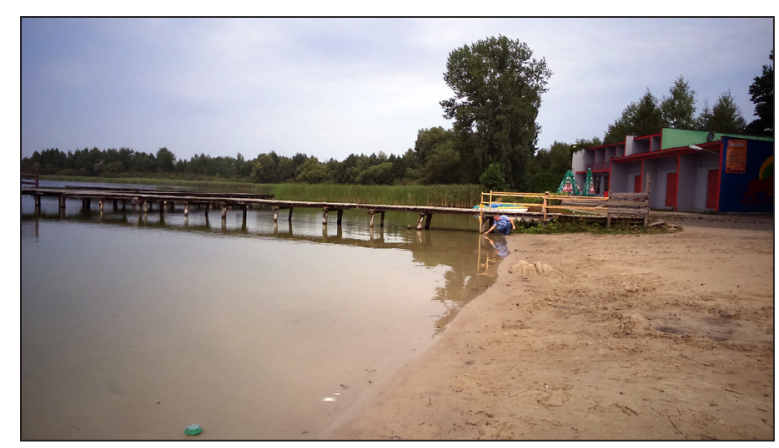

Photo 4. Sampling point no. 8

(photo: M. Gizińska-Górna)

with norms set forth in the Regulation of the Minister of Health of 8 April 2011 on the monitoring of the quality of bathing water [Regulation of the Minister of Health 2011]. The quality of water from wells was compared with the requirements set forth in the Regulation of the Minister of Health of 29 March 2007 on the quality of water for human consumption [Regulation of the Minister of Health, 2007] and the amending act [Regulation of the Minister of Health, 2010], and in the Regulation of the Minister of Environment [2008] on the criteria and method of evaluating the status of groundwaters.

\section{RESULTS AND DISCUSSION}

\section{Groundwaters}

Based on own studies, the authors found that the analysed water from the well satisfied the requirements for drinking water in terms of the content of nitrates, phosphates, chlorides and potassium. In single cases the standard concentrations of ammonia, nitrites, sulphates and iron were exceeded. The concentration of ammonia at point no. 1 in August was $0.75 \mathrm{mg} \cdot \mathrm{dm}^{-3}$ and was higher than the admissible concentration $(0.50$ $\mathrm{mg} \cdot \mathrm{dm}^{-3}$ ) determined in the Regulations of the Minister of Health [2007, 2010]. Pawęska et al. [2012] report that the presence of $\mathrm{NH}_{4}$ in water can be a result of polluting water with industrial or household sewage, and consequently the taste and smell of water is deteriorated. For the content of nitrites the admissible concentration $(0.50$ $\mathrm{mg} \cdot \mathrm{dm}^{-3}$ ) was exceeded at point no. 3 in May; it was $0.71 \mathrm{mg} \cdot \mathrm{dm}^{-3}$ (Table 1 ).

An indicator of poor quality of water in the wells is the content of sulphates. The admissible concentration of sulphates in drinking water 
is $250 \mathrm{mg} \cdot \mathrm{dm}^{-3}$. The analyses found that the admissible standard level was exceeded at measuring point number 1 in May $\left(279 \mathrm{mg} \cdot \mathrm{dm}^{-3}\right)$ and in June $\left(257 \mathrm{mg} \cdot \mathrm{dm}^{-3}\right)$.

The highest admissible concentration of iron in drinking water is $0.2 \mathrm{mg} \cdot \mathrm{dm}^{-3}$ [Regulation of the Minister of Health 2007, 2010]. In most analysed samples from dug wells the content of iron did not exceed this level, except samples taken at point no. 1 in August and November and at point no. 2 - in May (Tab. 1). According to WHO guidelines [2014] regarding the quality of drinking water, iron at concentrations higher than 0.2 $\mathrm{mg} \cdot \mathrm{dm}^{-3}$ stains clothes and sanitary appliances. Long-term consumption of water containing more than $0.6 \mathrm{mg} \cdot \mathrm{dm}^{-3}$ of iron causes bone and joint lesions and growth disorders in humans, and the concentration $0.05-0.1 \mathrm{mg} \cdot \mathrm{dm}^{-3}$ can increase the turbidity of water.

One thing negatively affecting the properties of water is the content of manganese. According to the Regulations of the Minister of Health [2007, 2010] the admissible concentration of manganese in drinking water is $0.05 \mathrm{mg} \cdot \mathrm{dm}^{-3}$. Its increased content causes the formation of suspended solids, making water turbid [Radzka et al. 2008], and excessive content of manganese contributes to damage of capillary vessel walls and has a toxic effect irritating the central nervous system and causes cirrhosis. In all analysed samples of water from wells the standard con- tent of manganese was exceeded (Table 1). Tests also revealed that this indicator was seasonally variable - except point no. 3, the highest concentrations of manganese were recorded in June. A similar excess of manganese in water from the wells was observed by Jóźwiakowski et al. [2014] and Pieńko et al. [2014].

Additionally, the quality of water from dug wells was compared with the requirements set forth in the Regulation of the Minister of Environment of 2008 on the criteria and method of evaluating the status of groundwaters. The quality of the analysed water was not satisfactory. Due to the concentrations of nitrites, phosphates and sulphates, in single cases values characteristic of IV purity class water were recorded. Potassium values corresponding to class IV and $\mathrm{V}$ were recorded for the majority of the analysed samples. The remaining chemical parameters fulfilled standards for water of satisfactory and even very good quality [Regulation of the Minister of Environment, 2008].

The microbiological status of water is a significant factor from the point of view of human health. The constant presence or sudden occurrence of pathogenic bacteria in drinking water creates a hazard of numerous contagious diseases occurring and spreading that in consequence can lead to epidemics. Microbiological testing of water from wells in Biakka showed that its quality was very poor.

Table 1. Quality of water from the wells in the catchment area of the Bialskie Lake in 2015

\begin{tabular}{|c|c|c|c|c|c|c|c|c|c|c|c|c|c|c|c|c|}
\hline \multirow{3}{*}{ Parameters } & \multicolumn{16}{|c|}{ Sampling points } \\
\hline & \multicolumn{4}{|c|}{1} & \multicolumn{4}{|c|}{2} & \multicolumn{4}{|c|}{3} & \multicolumn{4}{|c|}{4} \\
\hline & V & $\mathrm{VI}$ & VIII & $\mathrm{XI}$ & V & $\mathrm{VI}$ & VIII & $\mathrm{XI}$ & V & VI & VIII & $\mathrm{XI}$ & V & $\mathrm{VI}$ & VIII & $\mathrm{XI}$ \\
\hline $\mathrm{pH}$ & 7.01 & 6.67 & 6.67 & 6.83 & 7.04 & 6.47 & 6.26 & 6.75 & 7.17 & 7.09 & 7.28 & 7.04 & 7.14 & 7.16 & 6.35 & 7.09 \\
\hline Conductivity $\left[\mu \mathrm{S} \cdot \mathrm{cm}^{-1}\right]$ & 846 & 737 & 632 & 613 & 660 & 561 & 795 & 663 & 663 & 793 & 490 & 459 & 430 & 268 & 218 & 268 \\
\hline $\mathrm{NH}_{4}\left[\mathrm{mg} \cdot \mathrm{dm}^{-3}\right]$ & 0.23 & 0.32 & 0.75 & 0.25 & 0.05 & 0.03 & 0.12 & 0.03 & 0.12 & 0.10 & 0.09 & 0.01 & 0.24 & 0.05 & 0.04 & 0.01 \\
\hline $\mathrm{NO}_{3}\left[\mathrm{mg} \cdot \mathrm{dm}^{-3}\right]$ & 3.11 & 3.66 & 5.12 & 0.69 & 3.53 & 4.17 & 5.03 & 0.88 & 6.00 & 4.16 & 4.75 & 0.48 & 3.09 & 2.88 & 3.48 & 0.40 \\
\hline $\mathrm{NO}_{2}\left[\mathrm{mg} \cdot \mathrm{dm}^{-3}\right]$ & 0.14 & 0.04 & 0.14 & 0.04 & 0.17 & 0.02 & 0.03 & 0.02 & 0.71 & 0.13 & 0.02 & 0.08 & 0.11 & 0.02 & 0.00 & 0.01 \\
\hline $\begin{array}{l}\text { Phosphates } \\
{\left[\mathrm{mg} \mathrm{PO}_{4} \cdot \mathrm{dm}^{-3}\right]}\end{array}$ & 3.425 & 4.460 & 0.148 & 0.491 & 2.993 & 4.775 & 0.703 & 0.300 & 1.596 & 2.013 & 0.936 & 0.386 & 0.083 & $<0.010$ & 0.010 & 0.215 \\
\hline Chlorides [mg Cl. $\mathrm{dm}^{-3}$ ] & 47.7 & 43.8 & 46.7 & 37.3 & 14.6 & 14.6 & 47.2 & 29.3 & 40.8 & 91.2 & 47.3 & 47.9 & 20.1 & 10.7 & 8.6 & 10.3 \\
\hline Sulphates $\left[\mathrm{mg} \mathrm{SO}_{4} \cdot \mathrm{dm}^{-3}\right]$ & 279 & 257 & 188 & 186 & 215 & 150 & 194 & 244 & 164 & 175 & 157 & 130 & 82 & 62 & 39 & 62 \\
\hline Potassium $\left[{\left.\mathrm{mg} \mathrm{K} \cdot \mathrm{dm}^{-3}\right]}\right.$ & 50.6 & 54.6 & 65.8 & - & 22.8 & 33.6 & 44.6 & - & 56.0 & 26.8 & 18.9 & - & 14.8 & 21.6 & 27.0 & - \\
\hline Iron [mg Fe. $\mathrm{dm}^{-3}$ ] & 0.17 & 0.12 & 0.31 & 0.27 & 0.22 & 0.07 & 0.08 & 0.19 & 0.06 & 0.06 & 0.07 & 0.08 & 0.11 & 0.04 & 0.08 & 0.12 \\
\hline Manganese $\left[\mathrm{mgMn} \cdot \mathrm{dm}^{-3}\right]$ & - & 0.6 & 0.5 & 0.4 & - & 0.6 & 0.4 & 0.5 & - & 0.2 & 0.2 & 0.3 & - & 0.3 & 0.2 & 0.2 \\
\hline $\begin{array}{l}\text { Coli bacteria }[\mathrm{NPL} \cdot 100 \\
\left.\mathrm{cm}^{3}\right]\end{array}$ & $2.3 \cdot 10$ & $7.0 \cdot 10^{2}$ & $7.0 \cdot 10^{2}$ & $2.3 \cdot 10$ & $2.3 \cdot 10$ & $6.2 \cdot 10$ & $1.3 x \cdot 10^{2}$ & $7.0 \cdot 10^{2}$ & $6.2 \cdot 10$ & $7.0 \cdot 10^{2}$ & $2.4 \cdot 10^{2}$ & $2.3 \cdot 10$ & $2.3 \cdot 10$ & $2.4 \cdot 10^{3}$ & $2.4 \cdot 10^{2}$ & $2.4 \cdot 10^{2}$ \\
\hline $\begin{array}{l}\text { Faecal coliforms } \\
{\left[\mathrm{NPL} \cdot 100 \mathrm{~cm}^{3}\right]}\end{array}$ & $<5$ & $6.2 \cdot 10$ & $<5$ & $2.3 \cdot 10$ & $<5$ & $<5$ & 6.0 & $<5$ & 6.0 & $<5$ & $2.3 \cdot 10$ & $<5$ & $<5$ & $<5$ & $2.3 \cdot 10$ & $2.3 \cdot 10$ \\
\hline $\begin{array}{l}\text { Faecal Enterococci } \\
{\left[\mathrm{NPL} \cdot 100 \mathrm{~cm}^{-3}\right]}\end{array}$ & 4.0 & $4.6 \cdot 10^{2}$ & $2.3 \cdot 10$ & 9.0 & $9.3 \cdot 10$ & $2.3 \cdot 10^{3}$ & $2.3 \cdot 10$ & $2.8 \cdot 10$ & $2.3 \cdot 10$ & $2.4 \cdot 10^{2}$ & $4.3 \cdot 10$ & $<3$ & 9.0 & $4.3 \cdot 10$ & $1.5 \cdot 10^{2}$ & $2.3 \cdot 10$ \\
\hline $\begin{array}{l}\text { OLD psychrophiles } \\
{\left[\mathrm{CFU} \cdot \mathrm{ml}^{-1}\right]}\end{array}$ & $3.2 \cdot 10^{4}$ & $1.4 \cdot 10^{3}$ & $5.6 x \cdot 10^{3}$ & $1.5 \cdot 10^{3}$ & $5.1 \cdot 10$ & $2.6 \cdot 10^{3}$ & $1.2 x \cdot 10^{4}$ & $2.6 \cdot 10^{3}$ & $2.0 \cdot 10$ & $5.4 \cdot 10^{4}$ & $9.2 \cdot 10^{2}$ & $7.8 \cdot 10^{2}$ & $1.4 \cdot 10^{3}$ & $4.3 \cdot 10^{3}$ & $1.7 \cdot 10^{4}$ & $1.8 \cdot 10^{3}$ \\
\hline $\begin{array}{l}\text { OLD mesophiles } \\
{\left[\mathrm{CFU} \cdot \mathrm{ml}^{-1}\right]}\end{array}$ & $2.0 \cdot 10^{4}$ & $2.0 \cdot 10$ & $6.5 \cdot 10^{2}$ & $3.0 \cdot 10^{2}$ & $1.2 \cdot 10$ & $3.1 \cdot 10$ & $6.2 \cdot 10^{3}$ & $8.7 \cdot 10^{3}$ & $5.0 \cdot 10$ & $5.9 \cdot 10^{2}$ & $2.3 \cdot 10^{2}$ & $1.7 \cdot 10^{2}$ & $3.4 \cdot 10$ & $6.3 \cdot 10$ & $6.7 \cdot 10^{2}$ & $3.1 \cdot 10^{2}$ \\
\hline
\end{tabular}


The basic microbiological indicator taken into account in the assessment of the sanitary condition of water is the content of Coli bacteria. Regulations of the Minister of Health [2007, 2010] do not allow any presence of Coli bacteria in drinking water. The studies of the present authors indicate that in terms of the presence of Coli bacteria none of the analysed samples complied with the above-mentioned requirements. The count of these bacteria ranged from 2.3.10 to $2.4 \cdot 10^{3} \mathrm{NPL} \cdot 100 \mathrm{~cm}^{-3}$ (Tab. 1). Contamination with faecal coliforms was observed in $44 \%$ of the analysed samples. The highest count of bacteria from this group was recorded at point no. 1 in June $-6.2 \cdot 10 \mathrm{NPL} \cdot 100 \mathrm{~cm}^{-3}$ (Tab. 1). At this point in November the ratio of faecal coliforms to all Coli bacteria was 0.7 higher, which forms evidence that the water is contaminated with anthropogenic faeces [Korzeniewska and Niewolak 1999]. Such pollutants normally increase the content of nitrogen in the form of ammonia that was not found in the analysed samples. When at the same time the content of nitrates is high, one may suppose that quite a long time has passed since the time of sampling and the ammonia form could have been oxidised.

An additional indicator of the sanitary pollution of water is the presence of faecal Enterococci. According to the Regulations of the Minister of Health [2007, 2010], a $100 \mathrm{~cm}^{3}$ water sample should not contain any faecal Enterococci since contamination with this bacteria is a direct threat to human health. In the authors' own studies significant amounts of this bacteria were found in nearly $94 \%$ of the cases. The count of faecal Enterococci ranged from $<3$ to $2.3 \cdot 10^{3} \mathrm{NPL} \cdot 100$ $\mathrm{cm}^{-1}$ (Tab. 1). In nearly all measurement points the highest concentrations of these bacteria were recorded in June.

The assessment of the bacteriological quality of water from wells in the catchment area of Lake Bialskie also took into account the total count of psychrophiles (growing at the temp. of $22^{\circ} \mathrm{C}$ ) and mesophiles (growing at the temp. of $37^{\circ} \mathrm{C}$ ). The total count of psychrophiles in water from the wells ranged from $2.0 \cdot 10$ to $5.4 \cdot 10^{4} \mathrm{CFU} \cdot \mathrm{cm}^{-3}$, while that of mesophiles - from $1.2 \cdot 10$ to $2.0 \cdot 10^{4}$ $\mathrm{CFU} \cdot \mathrm{cm}^{-3}$ (Tab. 1). The count of psychrophiles exceeded the highest admissible value for drinking water by $88 \%$, that is, $100 \mathrm{CFU} \cdot \mathrm{cm}^{-3}$ [Regulation of the Minister of Health 2007, 2010]. Only in May at points no. 2 and 3 did the count of psychrophilic bacteria not exceed the standard level. In addition, it was determined that the admissible count of mesophilic bacteria specified in Regulations of the Minister of Health [2007, 2010] (50 CFU $\cdot \mathrm{cm}^{-3}$ ) was exceeded in nearly $69 \%$ of the cases. The count of these bacteria ranged from 1.2 10 to $2.0 \cdot 10^{4} \mathrm{CFU} \cdot \mathrm{cm}^{-3}$ and, as a rule, was higher in summer and autumn, which could be due to the intensive tourist traffic in that period (Tab.1).

The results of microbiological analyses of water from the wells in the village of Białka indicate that untreated water from these wells should not be drunk. The high count of indicator bacteria in these waters creates a serious direct hazard for human health and can cause many diseases. It can be assumed that the reason for the poor sanitary condition of groundwaters is anthropogenic pressure, mainly lack of a sewerage system in Białka and the related practice of disposing untreated household wastewater into soil as well as the raising farm animals and storage of organic fertilizers.

\section{Water from the Bialskie Lake}

The main chemical parameters taken into account in the assessment of quality of water from lakes are biogenic elements such as nitrogen and phosphorus. Taking into account the type of surface waters, including Lake Bialskie, in 4 cases the concentration of total phosphorus, which could contribute to the development of eutrophication, was found to exceed the standard level. The highest content of total phosphorus was recorded in autumn at three measurement points (no. 5,6 and 7) at point no. 7, in August (Tab. 2). As regards total phosphorus the lake waters did not exceed the standard determined in the Regulation of the Minister of Environment [2014] at the level $1.5 \mathrm{mg} \mathrm{P} \cdot \mathrm{dm}^{-3}$. The highest concentration of nitrogen in lake waters was recorded at point no. 6 in November (Tab. 2). In addition, the conductivity and dissolved oxygen were below the standard level.

In order to perform a more accurate assessment of the quality of waters in Lake Bialskie, additional physico-chemical parameters characterising surface waters were determined. Among analysed ratios high $\mathrm{COD}_{\mathrm{Cr}}$ and low $\mathrm{BOD}_{5}$ are noticeable. The $\mathrm{BOD}_{5}: \mathrm{COD}_{\mathrm{Cr}}$ ratio was in most cases lower than 1:10, which can form evidence of in- 
Table 2. Quality of water from the Bialskie Lake in 2015

\begin{tabular}{|c|c|c|c|c|c|c|c|c|c|c|c|c|c|c|c|c|}
\hline \multirow{3}{*}{ Parameters } & \multicolumn{16}{|c|}{ Sampling points } \\
\hline & \multicolumn{4}{|c|}{5} & \multicolumn{4}{|c|}{6} & \multicolumn{4}{|c|}{7} & \multicolumn{4}{|c|}{8} \\
\hline & V & VI & VIII & $X I$ & V & VI & VIII & $\mathrm{XI}$ & V & VI & VIII & $X I$ & V & VI & VIII & $X I$ \\
\hline Temperature $\left[{ }^{\circ} \mathrm{C}\right]$ & - & 24 & - & 13 & - & 23 & - & 13 & - & 22 & - & 14 & - & 23 & 22 & 14 \\
\hline $\mathrm{pH}$ & 7.89 & 8.59 & 8.33 & 7.82 & 8.09 & 8.53 & 8.38 & 7.85 & 8.35 & 8.59 & 8.67 & 7.87 & 8.48 & 8.66 & 8.73 & 7.87 \\
\hline $\begin{array}{l}\text { Dissolved oxygen } \\
{\left[\mathrm{mgO}_{2} \cdot \mathrm{dm}^{-3}\right]}\end{array}$ & 9.83 & 11.41 & 7.83 & 5.26 & 10.24 & 11.37 & 7.63 & 5.06 & 10.28 & 11.69 & 7.96 & 5.07 & 9.99 & 11.56 & 9.95 & 5.09 \\
\hline Conductivity $\left[\mu \mathrm{S} \cdot \mathrm{cm}^{-1}\right]$ & 346 & 250 & 228 & 272 & 276 & 250 & 221 & 271 & 279 & 249 & 229 & 269 & 280 & 254 & 230 & 273 \\
\hline $\begin{array}{l}\text { Total suspended solids } \\
{\left[\mathrm{mg} \cdot \mathrm{dm}^{-3}\right]}\end{array}$ & 7.90 & 6.50 & 6.25 & 4.61 & 2.60 & 1.60 & 8.06 & 8.45 & 5.30 & 1.60 & 4.76 & 4.17 & 10.00 & 1.60 & 3.50 & 10.61 \\
\hline $\mathrm{BOD}_{5}\left[\mathrm{mg} \mathrm{O}_{2} \cdot \mathrm{dm}^{-3}\right]$ & 2.10 & 2.58 & 3.52 & 1.83 & 1.53 & 2.35 & 3.49 & 0.36 & 3.23 & 4.34 & 2.47 & 1.88 & 1.90 & 3.12 & 5.31 & 2.51 \\
\hline $\mathrm{COD}_{\mathrm{Cr}}\left[\mathrm{mg} \mathrm{O}_{2} \cdot \mathrm{dm}^{-3}\right]$ & 33 & 29 & 29 & 18 & 25 & 24 & 30 & 8 & 28 & 23 & 33 & 10 & 25 & 25 & 35 & 9 \\
\hline $\mathrm{NH}_{4}\left[\mathrm{mg} \cdot \mathrm{dm}^{-3}\right]$ & 0.08 & 0.04 & 0.08 & 0.14 & 0.13 & 0.03 & 0.10 & 0.19 & 0.05 & 0.06 & 0.05 & 0.13 & 0.34 & 0.04 & 0.10 & 0.13 \\
\hline $\mathrm{NO}_{3}\left[\mathrm{mg} \cdot \mathrm{dm}^{-3}\right]$ & 1.99 & 2.13 & 1.91 & 0.43 & 2.33 & 1.14 & 1.31 & 0.38 & 1.66 & 1.87 & 1.49 & 0.33 & 1.66 & 2.12 & 1.66 & 0.28 \\
\hline $\mathrm{NO}_{2}\left[\mathrm{mg} \cdot \mathrm{dm}^{-3}\right]$ & 0.13 & 0.00 & 0.01 & 0.05 & 0.07 & 0.00 & 0.02 & 0.02 & 0.10 & 0.00 & 0.01 & 0.01 & 0.13 & 0.00 & 0.00 & 0.02 \\
\hline Total N [mg N $\cdot \mathrm{dm}^{-3]}$ & 0.2 & $<0.5$ & 0.6 & 0.9 & 0.1 & $<0.5$ & 0.4 & 1.1 & 0.1 & $<0.5$ & 0.2 & 0.7 & 0.5 & $<0.5$ & 0.3 & 0.8 \\
\hline $\mathrm{PO}_{4}\left[\mathrm{mg} \mathrm{PO}_{4} \cdot \mathrm{dm}^{-3}\right]$ & 0.153 & 0.015 & $<0.010$ & 0.100 & 0.192 & 0.010 & $<0.010$ & 0.062 & 1.373 & $<0.010$ & 0.032 & 0.099 & 0.396 & 0.036 & 0.018 & 0.036 \\
\hline Total P [mg P. $\left.\mathrm{dm}^{-3}\right]$ & 0.05 & 0.05 & 0.05 & 0.09 & 0.06 & 0.06 & 0.03 & 0.08 & 0.05 & 0.05 & 0.09 & 0.07 & 0.04 & 0.04 & 0.05 & 0.06 \\
\hline Chlorides [mg Cl. $\mathrm{dm}^{-3}$ ] & 32.1 & 12.4 & 14.3 & 17.6 & 13.7 & 12.8 & 13.8 & 15.5 & 14.1 & 13.4 & 13.0 & 14.4 & 11.9 & 14.6 & 13.3 & 15.5 \\
\hline $\begin{array}{l}\text { Sulphates [mg } \\
\left.\mathrm{SO}_{4} \cdot \mathrm{dm}^{-3}\right]\end{array}$ & 40 & 39 & 27 & 38 & 33 & 35 & 40 & 33 & 42 & 49 & 44 & 28 & 34 & 42 & 30 & 35 \\
\hline 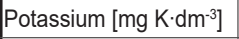 & 16.9 & 4.3 & 1.9 & 2.4 & 15.5 & 4.0 & 1.6 & 3.8 & 5.9 & 4.1 & 1.5 & 4.6 & 5.8 & 3.0 & 1.6 & 3.3 \\
\hline Iron [mg Fe $\left.\cdot \mathrm{dm}^{-3}\right]$ & 0.09 & 0.04 & 0.06 & 0.06 & 0.07 & 0.07 & 0.06 & 0.08 & 0.07 & 0.04 & 0.05 & 0.12 & 0.16 & 0.06 & 0.09 & 0.17 \\
\hline $\begin{array}{l}\text { Coli bacteria NPL } \cdot 100 \\
\mathrm{~cm}^{3}\end{array}$ & 6.0 & $6.2 \cdot 10$ & $2.4 \cdot 10^{2}$ & $2.4 \cdot 10^{2}$ & $2.4 \cdot 10^{3}$ & $2.4 \cdot 10^{3}$ & $2.4 \cdot 10^{2}$ & $2.4 \cdot 10^{3}$ & $2.4 \cdot 10^{2}$ & $2.3 \cdot 10$ & $5.0 \cdot 10$ & $2.4 \cdot 10^{2}$ & $2.3 \cdot 10$ & $2.3 \cdot 10$ & $6.2 \cdot 10$ & $2.4 \cdot 10^{2}$ \\
\hline $\begin{array}{l}\text { Faecal coliforms } \\
\mathrm{NPL} \cdot 100 \mathrm{~cm}^{3}\end{array}$ & $<5$ & $<5$ & $1.3 \cdot 10$ & $6.2 \cdot 10$ & $<5$ & $<5$ & $2.3 \cdot 10$ & $2.4 \cdot 10^{3}$ & $<5$ & $<5$ & 6.0 & $2.4 \cdot 10^{2}$ & $<5$ & $<5$ & 6.0 & $2.3 \cdot 10$ \\
\hline $\begin{array}{l}\text { Faecal Enterococci } \\
\mathrm{NPL} \cdot 100 \mathrm{~cm}^{-3}\end{array}$ & 4.0 & $<3$ & $4.3 \cdot 10$ & $<3$ & $<3$ & 9.0 & $4.3 \cdot 10$ & $<3$ & $<3$ & 4.0 & 7.0 & 3.0 & $<3$ & $<3$ & 4.0 & $<3$ \\
\hline $\begin{array}{l}\text { OLD psychrophiles } \\
\text { CFU } \cdot \mathrm{ml}^{-1}\end{array}$ & $3.7 \cdot 10$ & $1.5 \cdot 10^{4}$ & $9.1 \cdot 10^{2}$ & $2.4 \cdot 10^{4}$ & $1.5 \cdot 10^{3}$ & $2.7 \cdot 10^{4}$ & $9.7 \cdot 10^{3}$ & $5.8 \cdot 10^{3}$ & $7.2 \cdot 10^{2}$ & $9.2 \cdot 10^{2}$ & $1.8 \cdot 10^{2}$ & $4.2 \cdot 10^{3}$ & $2.0 \cdot 10$ & $1.7 \cdot 10^{3}$ & $1.3 \cdot 10^{2}$ & $2.9 \cdot 10^{4}$ \\
\hline $\begin{array}{l}\text { OLD mesophiles } \\
\text { CFU } \cdot \mathrm{ml}^{-1}\end{array}$ & $<10$ & $9.4 \cdot 10^{2}$ & $3.5 \cdot 10^{2}$ & $5.1 \cdot 10^{3}$ & $2.0 \cdot 10$ & $3.6 \cdot 10^{3}$ & $2.9 \cdot 10^{3}$ & $1.9 \cdot 10^{3}$ & $<10$ & $2.2 \cdot 10^{2}$ & $2.9 \cdot 10^{2}$ & $2.9 \cdot 10^{3}$ & $<10$ & $2.4 \cdot 10^{2}$ & $9.1 \cdot 10$ & $4.4 \cdot 10^{3}$ \\
\hline
\end{tabular}

tensive self-purification processes, including mineralisation of compounds sensitive to biochemical decomposition. The effect of this process is an increased content of stable compounds not susceptible to further biological decomposition. $\mathrm{COD}_{\mathrm{Cr}}$ ranged from 8 to $35 \mathrm{mg} \mathrm{O}_{2} \cdot \mathrm{dm}^{-3}$ (Tab. 2). Assuming standards determined for $\mathrm{COD}_{\mathrm{Cr}}$ in the Regulation of the Minister of Environment of 2004, the analysed waters can be assigned to purity class III or IV. Decomposition processes should result in an increased concentration of inorganic forms but this is visible only for phosphates in the springtime test series. This phenomenon can be also caused by the exchange of components between deep water and layers of bottom sediments. In summer, a decreasing content of phosphates was observed in all measuring points, most likely due to the intensification of primary production processes connected with an increased requirement of nutrients dissolved in water. It can also point to an increase in the $\mathrm{pH}$ of water and concentration of total nitrogen, and in particular its organic form. The highest concentration of phosphates was recorded at point no. 7, in May $-1.373 \mathrm{mg}$ $\mathrm{PO}_{4} \cdot \mathrm{dm}^{-3}$ (Tab. 2). Other indicators were within admissible ranges quoted in the Regulation of the Minister of Environment [2004].

Microbiological indicators were also determined in samples of water from Lake Bialskie. The count of Coli bacteria ranged from 6 to $2.4 \cdot 10^{3} \mathrm{NPL} \cdot \mathrm{cm}^{-3}$. The highest count of these bacteria in nearly every series of tests was recorded at measuring point no. 6 (Tab. 2). Assuming standards determined for Coli bacteria in the Regulation of the Minister of Environment of 2004, the analysed waters can be assigned to purity class II and III. According to the Regulation of the Minister of Health [2011], a $100 \mathrm{~cm}^{3}$ sample can contain $\leq 1000$ NPL of faecal coliforms, whereas the analysed samples of water contained from $<5$ to $2.4 \cdot 10^{3} \mathrm{NPL} \cdot \mathrm{cm}^{-3}$ (Tab. 2). The admissible count was exceeded at all measuring points in autumn, while at point no. 5 and 6 also in summer. The ratio of faecal coliforms to all Coli bacteria in lake 
water samples was mostly lower than 0.7 . The exception was sample no. 6 and 7 in November, where the quotient of the determined values was 1 , which forms evidence that water from the lake is contaminated with household sewage.

The count of faecal Enterococci in the analysed lake water ranged from $<3$ to $4.3 \cdot 10$ NPL $\cdot \mathrm{cm}^{-3}$. The highest count of these bacteria, significantly exceeding the admissible level, $\left(400 \mathrm{NPL} \cdot \mathrm{cm}^{-3}\right)$ was recorded in August at points no. 5 and 6 (Table 2).

In all water samples the count of psychrophilic bacteria deriving from runoffs (mainly from soil and air) was high. They are not pathogenic bacteria but due to the fact that they can show toxic effects, their count should be continuously monitored. The increase in their count above the standard can be a proof of the presence of easily assimilable organic compounds in water [Olańczuk-Neyman 2003]. The total count of psychrophilic bacteria in waters from Lake Bialskie ranged from $2.0 \cdot 10$ to $2.9 \cdot 10^{4} \mathrm{CFU} \cdot \mathrm{cm}^{-3}$. The highest concentrations of psychrophilic bacteria were recorded at point no. 5 in two test terms (June and November) and at point no. 6 (June) and 8 (November).

Sewage reaches surface waters along with bacteria occurring in the alimentary tract of humans and animals on a continuous basis - mesophilic bacteria. These bacteria often cause gastrointestinal diseases. The count of mesophilic bacteria is an indicator of the degree of sanitary pollution [Zabłocka-Godlewska et al. 1999]. In the analysed samples of water the count of mesophilic bacteria ranged from $<10$ to $5.1 \cdot 10^{3} \mathrm{CFU} \cdot \mathrm{cm}^{-3}$, which can testify that the water from the lake is contaminated with household sewage (Tab. 2).

The ratio between the total count of psychrophilic to mesophilic bacteria is an important indicator for evaluating water quality. According to data available in literature, if this ratio is higher than 10 , we can approximately classify the water as clean [Berleć et al. 2009]. Using this criterion only samples taken at points no. 6 and 7 in May (the ratios being 75 and 72 respectively) and at point no. 5 in June (ratio equal to 16) can be classified as clean waters. In other water samples the quotient of the total count of psychrophiles and mesophiles ranged from 0.62 to 7.5 , which indicates that water from Lake Bialskie contains anthropogenic pollutants.

\section{CONCLUSIONS}

1. The physico-chemical status of groundwaters from wells dug in the catchment area of Lake Bialskie makes it possible to classify them as water of unsatisfactory quality. The concentrations of nitrites, phosphates and sulphates in single cases corresponded to quality class IV, while for concentrations of potassium quality class $\mathrm{V}$.

2. The concentration of chemical pollutants in water from the wells in most cases satisfied the norms determined for drinking water. Manganese, the content of which regularly exceeded the standard level, was an exception.

3 . The factor disqualifying the quality of groundwater from the wells was the count of mesophilic and psychrophilic Coli bacteria, as well as faecal coliforms and faecal Enterococci. The degree of microbiological contamination of the analysed groundwaters points to possible contamination with household and farming sewage.

4. The concentration of chemical pollutants in the waters of Lake Bialskie was average. Concentrations above the standard level were recorded for phosphates only, which can be an effect of these compounds being released from bottom sediments.

5. In water from the lake a large count of mesoand psychrophilic bacteria and Coli bacteria, faecal coliforms was recorded. In summer, the count of faecal Enterococci was also high. High bacteria counts indicate that the analysed waters are contaminated with household sewage, which can be connected with increased tourist traffic around the lake in summer.

6 . The original reason for variable quality indicators in the water from Lake Bialskie is the influx of matter from outside, mainly with household sewage. As a consequence, ionic imbalance occurs in the reservoir, which can adversely affect the quality of water in the lake in the next few years.

7. In order to achieve a good status of water in the catchment area of Lake Bialskie, it is necessary to undertake decisive measures, in particular with regard to water and sewage management and rational use of the values of the lake and its surroundings for leisure purposes. 


\section{REFERENCES}

1. Bedla D., Król K. 2014. Effect of the use of the catchment area on the quality of water in a rural pond in the example of Zelków reservoir. Acta Scientarium Polonorum, Formatio Circumiectus, 13 (4), 25-33.

2. Berleć K., Jurek A., Michalska M., Traczykowski A. 2009. Microflora of recultivated water reservoirs in the example of Lake Rudnickie Wielkie. Rocznik Ochrona Środowiska, 11, 1029 - 1040.

3. Durkowski T., Woroniecki T. 2001. The quality of surface waters in the rural areas of West Pomerania (in Polish). Zeszyty Problemowe Postępów Nauk Rolniczych, 476, 365 - 371.

4. Grzywna A. 2014. Chemiczne wskaźniki jakości wody w zlewni lasów parczewskich. (Chemical indicators of water quality in the catchment area of the Parczew Forest), Inżynieria Ekologiczna, 36, 120-127.

5. Hermanowicz W., Dojlio W., Dożańska W., Koziorowski B., Zerbe J. 1999. Physico-chemical analysis of water and wastewater (in Polish). Arkady, Warszawa.

6. Jóźwiakowski K., Steszuk A., Pieńko A., Marzec M., Pytka A., Gizińska M., Sosnowska B. Ozonek J. 2014. Assessment of the impact of individual wastewater treatment plants with leach drains on the quality of groundwaters in dug wells and deep wells (in Polish). Inżynieria Ekologiczna, 39, 74-84.

7. Korzeniewska E., Niewolak S. 1999. Sanitary and bacteriological assessment of coastal waters in Lake Wigry (in Polish). [In:] S. Radwan, R. Kornijow (Ed.) Problemy aktywnej ochrony ekosystemów wodnych i torfowiskowych w polskich Parkach Narodowych (Issues of active protection of water and peatland ecosystems in Polish National Parks), Publisher UMCS, Lublin, 231-236.

8. Kuczynska-Kippen N., Nowosad P., Grzegorz G. 2004. Assessment of the quality of lake waters in the Greater Poland National Park and recreational reservoirs in the city of Poznań in springtime (in Polish). Roczniki Akademii Rolniczej w Poznaniu, CCCLXIII, 193-200.

9. Niemirycze E., Taylor R., Makowski Z. 1993. Biogenic hazards to surface waters (in Polish). Biblioteka Monitoringu Środowiska, PIOŚ, Warszawa.

10. Olańczuk-Neyman K. 2003. Microbiological aspects of disposing of sewage into coastal marine waters (in Polish). Inżynieria Morska i Geotechnika, 2, 55-62.

11. Pawęska K., Malczewska B., Zyglińska B. 2012. Characteristics of water from wells with particular emphasis on nitrogen compounds in the example of the village Przeździedz. Proceedings of ECOpole, 6 (1), 253-260.
12. Pieńko A., Steszuk A., Jóźwiakowski K., Marzec M., Pytka A., Gizińska M., Sosnowska B. 2014. Quality of groundwaters in an area particularly exposed to nitrogen pollution in the gmina Komarówka Podlaska (in Polish). Instal, 7/8, 69-73.

13. PN-C-04615-05:1975P. Water and wastewater. Microbiological testing. Determination of coliform bacteria by means of the fermentation test-tube method.

14. PN-C-04615-07:1977P. Water and wastewater. Microbiological testing. Determination of faecal coliform bacteria by means of the fermentation test-tube method.

15. PN-C-04615-25:2008P. Water and wastewater. Microbiological testing. Determination of faecal Enterococci by means of test-tube method.

16. PN-ISO 6222:1999. Water quality. Enumeration of culturable micro-organisms. Colony count by inoculation in a nutrient agar culture medium.

17. Radzka E., Koc G., Rak J. 2008. Assessment of the quality of drinking water in the poviat of Siedlce (in Polish). Przegląd Naukowy. Inżynieria i Kształtowanie Środowiska, 17, 3(41), 78-86.

18. Romańczuk T., Jóźwiakowski K., Gizińska M., Pytka A., Marzec M., Skwarzyńska A., Sosnowska B. 2013. Influence of anthropogenic contamination on quality of surface and underground waters in drainage basin of Lake Krasne. TEKA Komisji Ochrony i Kształtowania Środowiska Oddział PAN w Lublinie, X, 370-379.

19. Regulation of the Minister of Environment of 11 February 2004 on the classification for presentation of the status of surface waters and groundwaters, the method of monitoring and interpretation of results and presentation of the status of these waters.

20. Regulation of the Minister of Environment of 22 October 2014 on the method of classification of uniform parts of surface waters and environmental quality standards for priority substances.

21. Regulation of the Minister of Environment of 23 July 2008 on the criteria and methods of assessment of the status of groundwaters.

22. Regulation of the Minister of Health of 8 April 2011 on the monitoring of the quality of bathing water.

23. Regulation of the Minister of Health of 20 April 2010 amending the regulation on the quality of water for human consumption.

24. Regulation of the Minister of Health of 29 March 2007 amending the regulation on the quality of water for human consumption.

25. WHO 2014. Guidelines for drinking-water quality. Polish edition by the Chamber of Commerce Polish Waterworks, Bydgoszcz.

26. Regional Inspectorate for Environmental Protection 2006a. Communication about the status of 
purity and susceptibility to degradation of lakes analysed in 2005. Chełm.

27. Regional Inspectorate for Environmental Protection in Lublin 2006b. Report on the Status of the Environment in Lublin Voivodeship in 2005. Environmental Monitoring Library, Lublin.

28. Regional Inspectorate for Environmental Protection in Lublin 2014. Report on the Status of the
Environment in Lublin Voivodeship in 2014. Environmental Monitoring Library, Lublin.

29. Zabłocka-Godlewska E., Małachowska A., Mrozowska J. 1999. Environmental control for sanitary purposes (in Polish). [In:] J. Mrozowska (Ed.) Laboratorium $\mathrm{z}$ mikrobiologii ogólnej i środowiskowej (Laboratory of general and environmental microbiology).

Pracę dofinansowano ze środków Wojewódzkiego Funduszu Ochrony Środowiska i Gospodarki Wodnej w Lublinie. 